\title{
STRUKTUR DAN KOMPOSISI VEGETASI HABITAT BEKANTAN (Nasalis larvatus Wurmb. ) PADA HUTAN MANGROVE DI BAGIAN HILIR SUNGAI WAIN KALIMANTAN TIMUR*) (Structure and Composition of Proboscis Monkey's Habitat Vegetation in Mangrove Forest at Down Stream of Wain River, East Kalimantan)
}

\author{
Oleh/By: \\ Noorhidayah, Kade Sidiyasa, dan/and Amir Ma'ruf \\ Balai Penelitian Teknologi Perbenihan Samboja \\ Jl. Soekarno-Hatta Km 38 Po Box 319 Telp. (0542) 735206 Fax (0542) 413069 Balikpapan \\ dayahsamboja@yahoo.co.id; lokasamboja@yahoo.com \\ *) Diterima : 15 Mei 2006; Disetujui : 27 April 2007
}

\begin{abstract}
Structure and vegetation composition of proboscis monkey's habitat in mangrove forest at down stream of Wain River, East Kalimantan shows that in general the forest condition is heavily disturbed, which is indicated by a very low canopy, low forest density and the ground is covered by dense shrubs, lianas and other undergrowth plants. The vegetation composition consists of 22 species of trees and shrubs which belong to 20 genera and 18 families, and 18 species of undergrowth plants such as herbs, lianas, ferns, palms and pandanus. Based on the important value index (IVI) it was recognized that at the forest stage dominated by Heritiera littoralis Aiton, the sapling stage is also dominated by Heritiera littoralis Aiton which is associated with Pouteria obovata (R.Br.) Baehni and the seedling stage is dominated by Dillenia suffruticosa (Griff.) Mart.), Sonneratia caseolaris ( $L$ ) Engl. is one of tree species that produce food for proboscis monkey in the area beside a fern species of Acrostichum aureum Linn.
\end{abstract}

Key words : Vegetation, proboscis monkey, Nasalis larvatus Wurmb., structure and forest composition, Wain River, East Kalimantan

\begin{abstract}
ABSTRAK
Struktur dan komposisi vegetasi hutan mangrove habitat bekantan (Nasalis larvatus Wurmb.) di bagian hilir Sungai Wain, Kalimantan Timur menunjukkan bahwa pada habitat bekantan ini kondisi hutannya sudah sangat rusak yang ditandai oleh rendahnya tinggi tajuk teratas dari tegakan, rendahnya tingkat kerapatan pohon, dan rapatnya semak dan tumbuhan bawah yang menutupi lantai hutan. Komposisi vegetasi terdiri dari 22 jenis pohon yang termasuk ke dalam 20 marga dan 18 suku, serta 18 jenis tumbuhan bawah yang berupa herba, tumbuhan merambat, paku-pakuan, palem, dan pandan. Berdasarkan besarnya indeks nilai penting (INP), tingkat pohon didominasi oleh Heritiera littoralis Aiton, pada tingkat pancang juga didominasi oleh Heritiera littoralis Aiton yang berasosiasi dengan Pouteria obovata (R.Br.) Baehni, sedangkan pada tingkat semai didominasi oleh Dillenia suffruticosa (Griff.) Mart.). Sonneratia caseolaris (L) Engl. merupakan salah satu jenis pohon sebagai sumber pakan bagi bekantan selain satu jenis pakupakuan yakni Acrostichum aureum Linn.
\end{abstract}

Kata kunci : Vegetasi, bekantan, Nasalis larvatus Wurmb., struktur dan komposisi hutan, Sungai Wain, Kalimantan Timur

\section{PENDAHULUAN}

Habitat bagi satwa merupakan tempat hidup yang dapat memberikan perlindungan dan ketersediaan pakan yang cukup. Abercrombie et al., 1990 mendefinisikan habitat sebagai tempat atau lingkungan di mana organisme tertentu hidup di dalamnya. Pada ruang inilah satwa liar hidup dan berkembang biak, sebagaimana dikemukakan oleh Setia (1998) bahwa habitat merupakan suatu tempat atau tipe suatu tapak di mana 
organisme tertentu dan populasinya berinteraksi dan berkembang biak secara alami. Berbagai jenis makhluk hidup lain termasuk tumbuhan juga ada pada habitat satwa liar. Keanekaragaman jenis tumbuhan pada habitat satwa akan menentukan potensi dan jenis pakan, termasuk perilaku makan yang pada akhirnya menentukan populasi satwa itu di alam (Bismark et al., 2003).

Bekantan (Nasalis larvatus Wurmb.) merupakan salah satu jenis satwa arboreal yang langka dan terancam punah. Bekantan termasuk dalam Apendix I CITES (Convention of International Trade in Endangered Species of Wild Fauna and Flora), yaitu jenis yang jumlahnya di alam sudah sangat sedikit dan dikhawatirkan akan punah (Soehartono dan Mardiastuti, 2003). Penurunan populasi bekantan di beberapa kawasan hutan memberikan indikasi adanya gangguan terhadap kondisi habitat. Saat ini populasi bekantan di Kalimantan diperkirakan 114.000 individu dan dalam kurun waktu 10 tahun (1986-1995) telah terjadi penurunan populasi bekantan lebih dari $50 \%$ (Bismark et al., 2003). Penurunan populasi bekantan terus terjadi seiring dengan kerusakan habitat tempat hidupnya.

Kondisi habitat akan mempengaruhi kehidupan bekantan di alam. Keberadaan vegetasi memiliki keterkaitan yang erat dengan aktivitas bekantan di habitatnya. Bekantan memerlukan berbagai jenis tumbuhan untuk makan, tempat beristirahat, tempat tidur, berlindung, dan aktivitas lainnya. Komposisi vegetasi pada habitat bekantan perlu dikaji untuk mendukung upaya pelestarian satwa langka ini. Hal ini menyangkut komposisi dan struktur hutan beserta permudaannya termasuk tumbuhan bawah dengan berbagai habitusnya. Penyelamatan bekantan dan kawasan hutan bakau akan lebih berhasil apabila kondisi kawasan tersebut diketahui dengan baik. Penyelamatan satwa ini tidak terlepas dari kondisi habitat termasuk komposisi vegetasi yang menyusunnya, sehingga untuk melestarikan bekantan dan habitatnya di daerah sekitar hilir Sungai Wain Kalimantan Timur, salah satunya diperlukan data tentang struktur dan komposisi vegetasi di kawasan tersebut melalui suatu penelitian.

Tujuan dari penelitian ini adalah untuk mendapatkan informasi tentang struktur dan komposisi vegetasi pada habitat bekantan di daerah mangrove di bagian hilir Sungai Wain. Hasil penelitian ini diharapkan dapat memberikan masukan untuk pengelolaan habitat bekantan di hilir sampai di luar kawasan konservasi sebagai bagian integral dari upaya pelestariannya.

\section{METODOLOGI PENELITIAN}

Penelitian ini dilaksanakan pada hutan mangrove di bagian hilir Sungai Wain, Balikpapan, Provinsi Kalimantan Timur. Pengumpulan data vegetasi dilakukan dengan pembuatan petak-petak pengamatan berukuran $10 \mathrm{~m} \mathrm{x} 10 \mathrm{~m}$ untuk pohon, petak $5 \mathrm{~m}$ x $5 \mathrm{~m}$ untuk sapling, dan $2 \mathrm{~m}$ x $2 \mathrm{~m}$ untuk semai pada jalur-jalur pengamatan (jumlah jalur 6 dan jumlah petak 24). Jumlah petak contoh ini sudah dianggap cukup mewakili karena sisa hutan yang ada sudah sangat sempit, karena daerah sekitarnya sudah rusak. Panjang jalur pengamatan adalah $500 \mathrm{~m}$ dan peletakan petak-petak $5 \mathrm{~m}$ x 5 m dan petak-petak $2 \mathrm{~m}$ x 2 m dilakukan secara bersarang di dalam petak-petak yang berukuran $10 \mathrm{~m}$ x $10 \mathrm{~m}$. Seluruh jenis pohon di dalam petak pengamatan diidentifikasi dan diukur diameter batangnya.

Pengumpulan data dilakukan dalam bulan Juli 2004. Semua data yang diperoleh ditabulasikan dan selanjutnya diolah untuk mendapatkan indeks nilai penting. Indeks nilai penting ini merupakan nilai jumlah dari kerapatan relatif, dominansi relatif, dan frekuensi relatif.

Selanjutnya indeks nilai penting ini dijadikan dasar dalam menentukan tingkat dominasi suatu jenis pohon pada habitat bekantan. Untuk semai atau anakan pohon, indeks nilai penting suatu jenis 
hanya berdasarkan pada penjumlahan nilai kerapatan relatif dan frekuensi relatif. Vegetasi tumbuhan bawah (liana, herba, paku, palem, pandan, dan lain-lain) diamati secara kualitatif. Semua spesimen diidentifikasi secara lebih akurat di Herbarium Wanariset Samboja Kalimantan Timur.

\section{HASIL DAN PEMBAHASAN}

\section{A. Struktur Tegakan}

Berdasarkan pengamatan lapangan maka dapat dinyatakan bahwa kondisi hutan mangrove habitat bekantan di bagian hilir Sungai Wain sudah sangat rusak. Kondisi ini dicirikan oleh rendahnya tajuk teratas dari tegakan, rendahnya tingkat kerapatan pohon, dan rapatnya vegetasi semak dan tumbuhan bawah yang menutup lantai hutan. Lapisan tajuk paling atas hanya mencapai tinggi hingga $10 \mathrm{~m}$ dengan beberapa pohon-pohon dengan tajuk mencapai tinggi $15 \mathrm{~m}$. Pohonpohon tersebut adalah Heritiera littoralis Aiton (suku sterculiaceae) dengan diameter batang terbesar mencapai $47 \mathrm{~cm}$. Pohon-pohon dengan tinggi kurang dari 10 m ditemukan dalam jumlah 319 pohon (1.329,2 pohon/hektar). Sedangkan pohon-pohon dengan ketinggian antara 10-15 m hanya 17 pohon (70,8 pohon/ hektar). Dengan demikian maka habitat bekantan di Sungai Wain ini didominasi oleh pohon-pohon dengan ketinggian kurang dari $10 \mathrm{~m}$.

Kondisi yang demikian diduga akan dapat mempengaruhi aktivitas harian bekantan yang terkait dengan penggunaan strata hutan. Bismark (1986) melaporkan bahwa aktivitas sehari-hari anggota kelompok bekantan di hutan bakau Taman Nasional Kutai dilakukan pada puncak, pertengahan, dan bagian bawah tajuk, serta turun ke vegetasi tumbuhan bawah. Aktivitas makan dan istirahat bekantan lebih banyak terjadi pada strata yang berketinggian antara 10-15 m. Belum diketahui bagaimana perilaku adaptasi yang dilakukan oleh bekantan di kawasan penelitian sebagai akibat kurangnya jumlah pohon dengan ketinggian antara 10-15 m.

Berdasarkan sebaran kelas diameternya, pohon-pohon di bagian hilir Sungai Wain banyak ditemukan pada sebaran diameter kurang dari $10 \mathrm{~cm}$ yaitu 242 pohon $(1.008,3$ pohon/hektar). Pohon dengan diameter antara $10 \mathrm{~cm}$ dan $20 \mathrm{~cm}$ berjumlah 81 pohon (337,5 pohon/hektar), pada sebaran diameter antara $20 \mathrm{~cm}$ dan $30 \mathrm{~cm}$ terdapat tujuh pohon $(29,2$ pohon/hektar), sebaran diameter antara $30 \mathrm{~cm}$ dan $40 \mathrm{~cm}$ terdapat tiga pohon (12,5 pohon/hektar), dan hanya satu pohon (4,2 pohon/hektar) berdiameter lebih dari $40 \mathrm{~cm}$. Dari data ini terlihat adanya kecenderungan penurunan jumlah pohon seiring dengan kenaikan kelas diameternya yang dapat memberikan gambaran bahwa hutan mangrove pada habitat bekantan di bagian hilir Sungai Wain ini mempunyai proses permudaan alami yang normal.

Gambar 1 menunjukkan bahwa kenaikan kelas diameter sampai diameter < $40 \mathrm{~cm}$ berbanding lurus dengan tinggi rata-rata dan berbanding terbalik dengan jumlah individu pohonnya. Tetapi jumlah individu pohon dan tinggi rata-ratanya menurun pada kelas diamater yang lebih besar (diameter $\geq 40 \mathrm{~cm}$ ). Hal ini memberikan gambaran bahwa habitat bekantan pada lokasi penelitian didominasi oleh pohon-pohon muda. Pada kelas diamater yang kecil dengan tinggi rata-rata rendah, terdapat individu pohon dengan jumlah yang besar, sementara pada kelas diameter yang lebih besar dengan tinggi rata-rata yang semakin meningkat, terdapat individu pohon dengan jumlah yang semakin menurun.

\section{B. Komposisi dan Dominasi Jenis}

Hasil penelitian menunjukkan bahwa pada hutan mangrove di bagian hilir Sungai Wain terdapat 22 jenis pohon yang meliputi 20 marga dan 18 suku. Jenisjenis pohon yang ditemukan tersebut adalah jenis-jenis yang umum ditemukan 


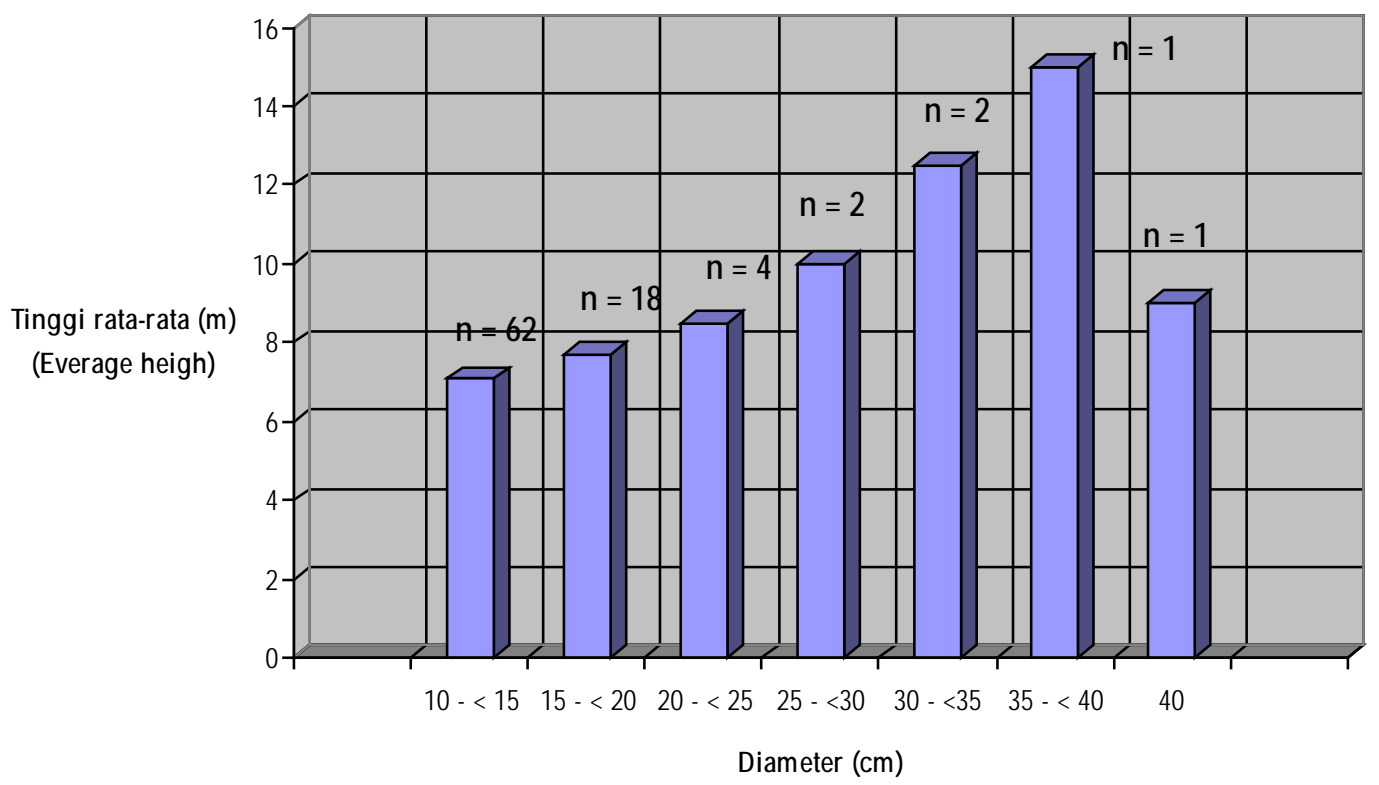

Gambar (Figure) 1. Hubungan antara tinggi dan diameter pohon pada hutan mangrove di hilir Sungai Wain (Correlation between the tree high and diameter in mangrove forest at down stream of Wain River)

pada hutan mangrove. Beberapa jenis di antara pohon-pohon tersebut ditemukan pada berbagai tingkatan pertumbuhan, baik pada tingkat pohon, pancang maupun semai. Pada tingkat pohon teridentifikasi sebanyak delapan jenis tumbuhan dari delapan marga dan delapan suku, pada tingkat pancang terdapat sebanyak 18 jenis dari 17 marga dan 15 suku, dan pada tingkat semai sebanyak delapan jenis dari tujuh marga dan tujuh suku. Cerbera manghas Linn., Pouteria obovata (R.Br.) Baehni, dan Aglaia sp. merupakan jenis-jenis yang ada pada semua tingkatan pertumbuhan. Sonneratia caseolaris (L) Engl. dan Bruguiera sp. merupakan jenis yang hanya terdapat pada tingkat pohon. Selebihnya merupakan jenis-jenis tumbuhan hanya ditemukan pada tingkat pancang dan semai, yakni Glochidion littorale Blume, Dillenia suffruticosa (Griff.) Mart.), dan Melastoma malabathricum Linn. (Tabel 1).

Ditinjau dari tingkat dominasi setiap jenis dalam tegakan, maka habitat bekantan di hutan mangrove di bagian hilir Sungai Wain pada tingkat pohon didominasi oleh jenis $H$. littoralis. Indeks ni- lai penting dari jenis ini adalah 103,34 \%, kemudian diikuti oleh $C$. manghas (INP $=83,81 \%)$ dan Oncosperma horidum (INP $=43,07 \%$ ). Komposisi jenis berdasarkan indeks nilai penting pada tingkat pohon disajikan pada Tabel 2.

Pada tingkat pancang, habitat bekantan didominasi oleh dua jenis pohon yang memiliki INP yang hampir sama. Kedua jenis pohon tersebut adalah $H$. littoralis (INP $=53,77 \%$ ) dan P. obovata (INP $=53,67 \%)$. Selain kedua jenis tersebut, beberapa jenis yang juga memiliki INP yang tinggi adalah Aglaia sp. (INP = 43,44 \%), Ardisia elliptica (INP = 39,18 $\%)$, G. littorale (INP= 34,72 \%), dan C. manghas (INP $=26,97 \%$ ). Jenis pohon lainnya memiliki INP yang jauh di bawah jenis-jenis tersebut. Komposisi jenis berdasarkan indeks nilai penting pada tingkat pancang disajikan pada Tabel 3.

Sedangkan pada tingkat semai, habitat bekantan di bagian hilir Sungai Wain ini didominasi oleh $D$. suffruticosa yang mempunyai INP sebesar 42,84\%, kemudian diikuti oleh tiga jenis yang secara bersama-sama dengan INP masingmasing 28,57 \% yakni C. manghas, 
Aglaia sp., dan G. littorale (Tabel 4). Semai merupakan permudaan suatu jenis tumbuhan di alam. Keberadaan suatu jenis pohon pada tingkat semai dapat memberikan gambaran tentang permudaan jenis tersebut dan kelangsungan hidup jenis itu pada masa mendatang. Komposisi jenis berdasarkan indeks nilai penting pada tingkat semai disajikan pada Tabel 4 .

Tabel (Table) 1. Jenis- jenis pohon pada tiga tingkatan pertumbuhan yang diidentifikasi di hutan mangrove di Sungai Wain (Tree species at three growth level identified in mangrove forest at Wain River)

\begin{tabular}{|c|c|c|c|}
\hline $\begin{array}{c}\text { Tingkat pertumbuhan } \\
\text { (Growth level) }\end{array}$ & $\begin{array}{c}\text { Suku } \\
\text { (Family) }\end{array}$ & $\begin{array}{c}\text { Jenis } \\
\text { (Species) }\end{array}$ & $\begin{array}{c}\text { Jumlah individu/240 } \mathrm{m}^{2} \\
\text { (Number of individu/240 } \mathrm{m}^{2} \text { ) }\end{array}$ \\
\hline \multirow[t]{8}{*}{ Pohon (Tree) } & Apocynaceae & Cerbera manghas Linn. & 23 \\
\hline & Meliaceae & Aglaia sp. & 7 \\
\hline & Sterculiaceae & Heritiera littoralis Aiton & 25 \\
\hline & Palmae & $\begin{array}{l}\text { Oncosperma horridum } \\
\text { (Griff.) Scheff. }\end{array}$ & 15 \\
\hline & Leguminosae & Cynometra ramiflora Linn. & 1 \\
\hline & Sonneratiaceae & $\begin{array}{l}\text { Sonneratia caseolaris (L) } \\
\text { Engl. }\end{array}$ & 3 \\
\hline & Sapotaceae & $\begin{array}{l}\text { Pouteria obovata (R.Br.) } \\
\text { Baehni }\end{array}$ & 8 \\
\hline & Rhizoporaceae & Bruguira sp. & 1 \\
\hline \multirow[t]{18}{*}{ Pancang (Sapling) } & Euphorbiaceae & Glochidion littorale Blume & 31 \\
\hline & Apocynaceae & Cerbera manghas Linn. & 14 \\
\hline & Meliaceae & Aglaia sp. & 25 \\
\hline & Sterculiaceae & Heritiera littoralis Aiton & 45 \\
\hline & Palmae & $\begin{array}{l}\text { Oncosperma horridum } \\
\text { (Griff.) Scheff. }\end{array}$ & 4 \\
\hline & Leguminosae & Cynometra ramiflora Linn. & 5 \\
\hline & & $\begin{array}{l}\text { Intsia bijuga (Colebr.) } \\
\text { Kuntze }\end{array}$ & 1 \\
\hline & Sapotaceae & $\begin{array}{l}\text { Pouteria obovata (R.Br.) } \\
\text { Baehni }\end{array}$ & 47 \\
\hline & Myrsinaceae & Ardisia elliptica Thunb. & 40 \\
\hline & Melastomataceae & $\begin{array}{l}\text { Melastoma malabathricum } \\
\text { Linn. }\end{array}$ & 3 \\
\hline & & Melastoma sp. & 1 \\
\hline & & Memecylon edule Roxb. & 4 \\
\hline & Aquifoliaceae & Ilex sp. & 7 \\
\hline & Dilleniaceae & $\begin{array}{l}\text { Dillenia suffruticosa (Griff.) } \\
\text { Mart.) }\end{array}$ & 3 \\
\hline & Sapindaceae & Guioa cf.diplopetala (Hass.) & 4 \\
\hline & Verbenaceae & $\begin{array}{l}\text { Premna corymbosa Rottl. \& } \\
\text { Willd. }\end{array}$ & 1 \\
\hline & Myrtaceae & Eugenia stapfiana King & 3 \\
\hline & Rubiaceae & Ixora sp. & 1 \\
\hline \multirow[t]{8}{*}{ Semai (seedling) } & Lecythidaceae & Barringtonia sp. & 1 \\
\hline & Apocynaceae & Cerbera manghas Linn. & 2 \\
\hline & Dilleniaceae & $\begin{array}{l}\text { Dillenia suffruticosa (Griff.) } \\
\text { Mart.) }\end{array}$ & 3 \\
\hline & Euphorbiaceae & Glochidion littorale Blume & 2 \\
\hline & Melastomataceae & $\begin{array}{l}\text { Melastoma malabathricum } \\
\text { Linn. }\end{array}$ & 1 \\
\hline & & Melastoma sp. & 2 \\
\hline & Sapotaceae & $\begin{array}{l}\text { Pouteria obovata (R.Br.) } \\
\text { Baehni }\end{array}$ & 1 \\
\hline & Meliaceae & Aglaia sp. & 2 \\
\hline
\end{tabular}


Tabel (Table) 2. Dominasi pohon setiap jenis berdasarkan indeks nilai penting pada habitat bekantan di Sungai Wain (Dominance level of each tree species based on important value index at the proboscis monkey habitats in Wain River)

\begin{tabular}{lcccc}
\hline \multicolumn{1}{c}{ Jenis tumbuhan (Plant species) } & KR (\%) & DR (\%) & FR (\%) & INP (\%) \\
\hline Heritiera littoralis & 26,88 & 46,23 & 30,23 & 103,34 \\
Cerbera manghas & 35,48 & 32,04 & 16,28 & 83,81 \\
Oncosperma horidum & 16,13 & 8,34 & 18,60 & 43,07 \\
Pouteria obovata & 8,60 & 5,62 & 13,95 & 28,18 \\
Aglaia sp. & 7,53 & 4,21 & 13,95 & 25,69 \\
Sonneratia caseolaris & 3,22 & 2,46 & 2,32 & 8,01 \\
Bruguira sp. & 1,07 & 0,60 & 2,32 & 4,00 \\
Cynometra ramiflora & 1,07 & 0,49 & 2,32 & 3,89 \\
Keterangan (Remark) : KR = Kerapatan relatif (Relative density); DR = Dominansi relatif (Relative dominance); \\
\multicolumn{2}{r}{ FR = Frekuensi relatif (Relative frequency); INP = Indeks nilai penting (Important value index) }
\end{tabular}

Tabel (Table) 3. Urutan tingkat dominasi jenis berdasarkan indeks nilai penting pada tingkat pancang pada habitat bekantan di Sungai Wain (Rank of dominance level of each species based on important value index of sapling level at the proboscis monkey habitats in Wain River)

\begin{tabular}{lcccc}
\hline Jenis tumbuhan (Plant species) & KR (\%) & FR (\%) & DR (\%) & INP (\%) \\
\hline Heritiera littoralis & 18,83 & 12,50 & 22,44 & 53,77 \\
Pouteria obovata & 19,67 & 10,27 & 23,78 & 53,67 \\
Aglaia sp. & 10,46 & 13,63 & 19,34 & 43,44 \\
Ardisia elliptica & 16,74 & 14,77 & 7,67 & 39,18 \\
Glochidion littorale & 12,97 & 15,91 & 5,84 & 34,72 \\
Cerbera manghas & 5,86 & 9,09 & 12,02 & 26,97 \\
Oncosperma horidum & 1,67 & 3,41 & 4,29 & 9,38 \\
Cynometra ramiflora & 2,09 & 3,41 & 1,20 & 6,70 \\
Ilex sp. & 2,51 & 2,27 & 0,41 & 5,20 \\
Memecylon edule & 1,67 & 1,13 & 1,72 & 4,53 \\
Guioa cf. diplopetala & 1,67 & 2,27 & 0,16 & 4,11 \\
Dillenia suffruticosa & 1,25 & 2,27 & 0,32 & 3,84 \\
Melastoma malabathricum & 1,25 & 2,27 & 0,19 & 3,72 \\
Eugenia stapfiana & 1,25 & 2,27 & 0,11 & 3,64 \\
Ixora sp. & 0,42 & 1,13 & 0,23 & 1,79 \\
Premna corymbosa & 0,42 & 1,13 & 0,09 & 1,65 \\
Intsia bijuga & 0,42 & 1,13 & 0,09 & 1,64 \\
Melastoma sp. & 0,42 & 1,13 & 0,02 & 1,57 \\
\hline
\end{tabular}

Keterangan (Remark) : KR = Kerapatan relatif (Relative density); FR = Frekuensi relatif (Relative frequency); $\mathrm{DR}=$ Dominansi relatif (Relative dominance); INP = Indeks nilai penting (Important value index)

Tabel (Table) 4. Urutan tingkat dominasi jenis berdasarkan indeks nilai penting pada tingkat semai pada habitat bekantan di Sungai Wain (Rank of dominance level of each species based on important value index of seedling level at the proboscis monkey habitats in sungai Wain)

\begin{tabular}{lccc}
\hline \multicolumn{1}{c}{ Jenis tumbuhan (Plant species) } & KR (\%) & FR (\%) & INP (\%) \\
\hline Cerbera manghas & 14,28 & 14,28 & 28,57 \\
Aglaia sp. & 14,28 & 14,28 & 28,57 \\
Glochidion littorale & 14,28 & 14,28 & 28,57 \\
Melastoma sp. & 14,28 & 7,42 & 21,42 \\
Melastoma malabathricum & 7,14 & 14,28 & 21,42 \\
Barringtonia sp. & 7,14 & 7,14 & 14,28 \\
Dillenia suffruticosa & 21,42 & 21,42 & 42,84 \\
Pouteria obovata & 7,14 & 7,141 & 14,28 \\
\hline
\end{tabular}

Keterangan (Remark) : KR = Kerapatan relatif (Relative density); FR = Frekuensi relatif (Relative frequency) INP $=$ Indeks nilai penting (Important value index) 
Komposisi jenis yang mendominasi kawasan penelitian pada tingkat pohon, semai, dan pancang (Tabel 2, 3, dan Tabel 4) berbeda dengan komposisi jenis pada habitat bekantan lainnya di Kalimantan Timur. Di hutan mangrove Taman Nasional Kutai, vegetasi didominasi oleh jenis Rhizophora apiculata pada semua tingkat pertumbuhan (Bismark, 1999). Sedangkan habitat bekantan di Kuala Samboja didominasi oleh Sonneratia caseolaris pada tingkat pohon dan pancang (Sidiyasa, 2005). Kondisi ini juga berbeda dengan laporan Bismark et al. (2003) yang menyebutkan bahwa habitat satwa arboreal (seperti bekantan dan burung) di Kalimantan Timur hingga satu kilometer dari pantai didominasi oleh Rhizopora mucronata, Rhizopora apiculata, dan Bruguiera sexangula, sedangkan di kawasan ini vegetasinya didominasi oleh $H$. littoralis pada tingkat pohon dan pancang serta $D$. suffruticosa pada tingkat semai.

\section{Vegetasi Jenis Tumbuhan Bawah}

Berdasarkan pengamatan langsung di lapangan maka vegetasi tumbuhan bawah ini terdapat sebanyak 18 jenis yang meliputi 17 marga dan 14 suku. Jenis-jenis tumbuhan yang termasuk dalam kelompok ini adalah tumbuhan herba (4 jenis), tumbuhan merambat atau liana (9 jenis), paku-pakuan (3 jenis), palem (1 jenis), dan pandan (1 jenis) (Tabel 5). Hasil penelitian menunjukkan bahwa pada habitat bekantan di bagian hilir Sungai Wain ditemukan 19 jenis tumbuhan bawah dari 18 marga dan 15 suku. Tumbuhan bawah di kawasan ini ada yang berupa herba, paku, liana maupun palem.

Di antara jenis-jenis tumbuhan bawah seperti tersebut dalam Tabel 4, yang mempunyai pengaruh sangat nyata terhadap perkembangan dan proses regenerasi bagi vegetasi yang ada di atasnya adalah Acrostichum aureum, Nypa fructicans, dan Acanthus ebracteatus. Ketiga jenis tumbuhan tersebut umumnya menutup lantai hutan secara sangat rapat sehingga tidak memungkinkan bagi jenis-jenis tumbuhan lain, termasuk anakan pohon untuk tumbuh dan berkembang.

\section{Jenis Pohon Pakan, Pohon Tempat Beristirahat, dan Pohon Untuk Tidur}

Sonneratia caseolaris merupakan salah satu jenis pohon yang saat ini teridentifikasi sebagai sumber pakan paling umum bagi bekantan pada hutan mangrove

Tabel (Table) 5. Jenis-jenis tumbuhan bawah pada habitat bekantan di bagian hilir Sungai Wain (The undergrowth at the proboscis monkey habitat in lower part of Wain River)

\begin{tabular}{llll}
\hline No & & \multicolumn{1}{c}{ Suku (Family) } & Habitus (Life form) \\
\hline 1 & Dalbergia sp. & Leguminosae & Liana \\
2 & Salacia sp. & Celastraceae & Liana \\
3 & Ventilago sp. & Rhamnaceae & Liana \\
4 & Ficus sp. & Moraceae & Liana \\
5 & Jenis Rubiaceae yang tidak teridentifikasi & Rubiaceae & Liana \\
& (Unidentified species of Rubiaceae) & & \\
6 & Lygodium sp. & Schizaeaceae & Paku \\
7 & Nypa fructicans (Thumb.) Wurmb. & Palmae & Palem \\
8 & Acanthus obracteatus Vahl. & Acanthaceae & Liana \\
9 & Ischaemum muticum Linn. & Gramineae & Herba \\
10 & Oxyceros sp. & Rubiaceae & Liana \\
11 & Pandanus sp. & Pandanaceae & Pandan \\
12 & Flagellaria indica Linn. & Flagellaceae & Liana \\
13 & Alyxia sp. & Apocynaceae & Liana \\
14 & Mappania sp. & Cyperaceae & Herba \\
15 & Acrostichum aureum Linn. & Polipodiaceae & Paku \\
16 & Scleria sp. & Cyperaceae & Herba \\
17 & Lygodium sp. & Schizaeaceae & Paku \\
18 & Saccharum spontaneum Linn. & Gramineae & Herba \\
\hline
\end{tabular}


di bagian hilir Sungai Wain. Pada hutan mangrove di Taman Nasional Kutai, bekantan mengkonsumsi 10 jenis pohon pakan termasuk S. caseolaris (Bismark, 1986). Di lokasi penelitian, jenis ini jarang ditemukan dan bukan merupakan jenis yang dominan. Pada petak pengamatan hanya ditemukan tiga individu pohon $S$. caseolaris. Dominasi yang kecil dari jenis ini digambarkan dengan INP-nya yang hanya 8,01 \%. Sonneratia caseolaris hanya dijumpai di tepi sungai sampai ke belakang sejauh lima meter dengan ketinggian pohon rata-rata 6,6 m. Sonneratia caseolaris yang ada di kawasan ini juga bukan tergolong pohon yang besar. Diameter pohon yang dijumpai berkisar antara 12,7 cm hingga 15,3 cm. Permudaan alamnya tidak dijumpai di dalam petak-petak pengamatan. Dominasi jenis yang rendah dan tidak adanya permudaan alam akan dapat mengancam kelangsungan hidup bekantan di kawasan ini, mengingat $S$. caseolaris merupakan sumber pakan utama bekantan yang teridentifikasi di kawasan ini.

Kondisi ini akan semakin parah, karena bekantan akan terus mengkonsumsi pohon pakan yang jumlahnya tidak seimbang dengan populasi bekantan yang ada. Di wilayah ini terdapat empat kelompok bekantan (Ma'ruf, 2004). Tingginya tingkat konsumsi bekantan terhadap $S$. caseolaris memungkinkan terganggunya pertumbuhan dan regenerasi jenis ini. Di Cagar Alam Pulau Kaget (Kalimantan Selatan), bekantan melakukan penggundulan sebagian pucuk dan memakan ranting-ranting $S$. caseolaris sehingga menghambat/mengganggu pertumbuhan anakan (Akbar et al., 2002). Untuk mengatasi permasalahan yang dihadapi di cagar alam ini telah dilakukan berbagai upaya teknik rehabilitasi kawasan, salah satunya dengan pemeliharaan anakan alam dengan cara pemagaran yang ternyata hanya menurunkan kerusakan anakan akibat sampah dan tidak berpengaruh terhadap pertumbuhan anakan alam S. caseolaris (Akbar et al., 2002).
Daun merupakan bagian yang dikonsumsi bekantan sebagai pakan. Berkurangnya jumlah daun dapat mengganggu proses fotosintesis yang selanjutnya akan berakibat pada terganggunya pertumbuhan jenis tersebut. Daun yang dikonsumsi bekantan adalah daun muda (urutan 1 sampai 3 dari ujung ranting). Daun dimakan satu per satu atau sekaligus dua lembar dengan cara menggabungkannya (Bismark, 1999).

Rendahnya potensi $S$. caseolaratis yang merupakan pohon pakan bagi bekantan di bagian hilir Sungai Wain dan ketiadaan permudaannya pada tingkat pancang dan semai akan mengganggu kelangsungan hidup bekantan. Sebagai habitat bekantan kawasan ini seharusnya dapat menyediakan pakan yang cukup secara terus menerus. Kondisi ini serupa dengan kerusakan vegetasi pada habitat bekantan di Cagar Alam Pulau Kaget Kalimantan Selatan dan dikhawatirkan dapat menyebabkan punahnya bekantan di kawasan tersebut (Akbar et al., 2002).

Beberapa jenis pohon yang biasa dijadikan tempat untuk tidur, beristirahat, dan bersembunyi di antaranya adalah $H$. littoralis, S. caseolaratis, dan Nypa fructicans. Selain memanfaatkan pohon, bekantan juga seringkali bersembunyi pada tegakan $N$. fructicans (nipah). Kecenderungan bekantan memanfaatkan pohon $H$. littoralis mungkin karena jumlahnya yang banyak. Bismark (1986) mengemukakan bahwa pohon yang dipilih bekantan untuk beristirahat adalah pohon yang rimbun sehingga tubuhnya terhindar dari cahaya matahari langsung. Pada habitat yang telah rusak strategi pemilihan pohon tempat tidur dan perilaku berpindah-pindah setiap hari yang dilakukan bekantan akan lebih berperan dalam mempertahankan populasinya (Bismark, 2004).

\section{KESIMPULAN DAN SARAN}

\section{A. Kesimpulan}

1. Vegetasi mangrove yang merupakan habitat bekantan (Nasalis larvatus 
Wurmb.) di bagian hilir Sungai Wain, Kalimantan Timur, terdiri dari vegetasi yang kondisinya sudah sangat terganggu yang dicirikan oleh rendahnya tajuk teratas dari tegakan, rendahnya tingkat kerapatan pohon, dan rapatnya semak dan tumbuhan bawah yang menutup lantai hutan.

2. Jenis-jenis tumbuhan yang merupakan penyusun utama vegetasi meliputi pohon dan perdu sebanyak 22 jenis (dalam 20 marga dan 18 suku) serta 18 jenis tumbuhan bawah (dalam 17 marga dan 14 suku) berupa herba, paku-pakuan, liana, palem, dan pandan.

3. Berdasarkan besarnya indeks nilai penting (INP) suatu jenis maka jenisjenis tumbuhan yang paling dominan pada vegetasi tingkat pohon adalah Heritiera littoralis Aiton (INP = $103,34 \%$ ), pada tingkat pancang juga didominasi oleh Heritiera littoralis Aiton (INP $=54,77 \%$ ) yang membentuk asosiasi bersama Pouteria obovata (R.Br.) Baehni (INP = 54,67 $\%)$, dan pada tingkat semai didominasi oleh Dillenia suffruticosa (Griff.) Mart.) (INP $=42,84 \%$ ).

4. Sonneratia caseolaris (L) Engl. merupakan jenis pohon yang teridentifikasi sebagai sumber pakan paling utama bagi bekantan (Nasalis larvatus Wurmb.) pada hutan mangrove di bagian hilir Sungai Wain. Jenis lainnya adalah Acrostichum aureum Linn. (sejenis paku), namun jenis yang terakhir ini hanya dikonsumsi dalam jumlah yang sangat sedikit.

\section{B. Saran}

Dalam rangka upaya pelestarian bekantan (Nasalis larvatus Wurmb.) di bagian hilir Sungai Wain maka keberadaan hutan mangrove dengan kondisi seperti saat ini harus dipertahankan dan bila perlu dilakukan rehabilitasi hingga minimal selebar 100 m pada sisi kanan dan kiri sungai. Jika upaya tersebut tidak dapat dilakukan maka satu-satunya cara adalah dengan memindahkan atau menggiring kawanan bekantan (Nasalis larvatus Wurmb.) masuk ke kawasan Hutan Lindung Sungai Wain yang berbatasan langsung dengan kawasan mangrove tersebut.

\section{DAFTAR PUSTAKA}

Abercrombie, M., M. Hickman, M.L. Johnson and M. Thain. 1990. The New Penguin Dictionary of Biology. Clays. Ltd. England.

Akbar, A., E. Priyatno, H. A. Basaing, Manaon dan F. Rizani. 2002. Pengaruh Pemagaran Terhadap Pertumbuhan Awal Permudaan Rambai (Sonneratia caesolaris (L) Engl.) di Cagar Alam Pulau Kaget. Buletin Teknologi Reboisasi 9 : 42-53. Pusat Penelitian dan Pengembangan Bioteknologi dan Pemuliaan Tanaman Hutan. Yogyakarta.

Bismark, M. 1986. Aktivitas dan Pola Pergerakan Harian Bekantan di Hutan Bakau Taman Nasional Kutai, Kalimantan Timur. Buletin Penelitian Hutan 476 : 31-45. Pusat Penelitian dan Pengembangan Hutan. Bogor.

Bismark, M. 1999. Studi Ekologi Makan Bekantan (Nasalis larvatus) di Hutan Bakau Taman Nasional Kutai, Kalimantan Timur. Buletin Penelitian Kehutanan 13 (2) : 4256. Balai Penelitian Kehutanan Samarinda.

Bismark, M., S. Iskandar dan R. Sawitry. 2000. Pedoman Teknis Pengelolaan Bekantan (Nasalis larvatus) di Kalimantan. Info Hutan 121. Pusat Penelitian dan Pengembangan $\mathrm{Hu}-$ tan dan Konservasi Alam. Bogor.

Bismark, M., R. Garsetiasih, S. Iskandar, E. Subiandono, R. Sawitry dan N.M. Heriyanto. 2003. Daya Dukung Habitat sebagai Parameter Dominan dalam Pengelolaan Populasi Satwa Liar di Alam. Paket Teknologi P3H\&KA : 35-47. Pusat Penelitian dan Pengembangan Hutan dan Konservasi Alam. Bogor. 
Bismark, M. 2004. Daya Dukung Habitat dan Adaptasi Bekantan (Nasalis larvatus Wurmb.). Jurnal Penelitian Hutan dan Konservasi Alam I (3) : 309-320. Pusat Penelitian dan Pengembangan Hutan dan Konservasi Alam. Bogor.

Ma'ruf, A. 2004. Studi Perilaku Bekantan (Nasalis larvatus) di Daerah Balikpapan dan Sekitarnya. Makalah Seminar Hasil Penelitian dan Kegiatan Pelestarian Keanekaragaman Hayati Wilayah Kalimantan. Loka Penelitian dan Pengembangan Satwa Primata, Balikpapan.
Setia, A.Z. 1998. Kamus Kehutanan. PT. Rineka Cipta. Jakarta.

Sidiyasa, K., Noorhidayah dan A. Ma'ruf. 2005. Habitat dan Potensi Regenerasi Pohon Pakan Bekantan (Nasalis larvatus) di Kuala Samboja Kalimantan Timur. Jurnal Penelitian Hutan dan Konservasi Alam II (4) : 409-416. Pusat Penelitian dan Pengembangan Hutan dan Konservasi Alam. Bogor.

Soehartono, T. dan A. Mardiastuti. 2003. Pelaksanaan Konvensi CITES di Indonesia. Japan International Coorporation Agency, Jakarta. 